\title{
Features of the Oyster Mushroom Growth and Distribution in Suburban Forests and Urban Conditions of the Ukrainian Roztochya
}

\author{
Vasil Popovych ${ }^{1 *}$, Oleksandra Dyda ${ }^{2}$,Nataliya Popovych ${ }^{3}$, Mykhailo Les $^{4}$ \\ 1 Institute of Civil Protection, Lviv State University of Life Safety, Kleparivska Str. 35, Lviv, 79000, Ukraine \\ 2 Institute of Architecture and Design, Lviv Polytechnic National University, S. Bandera Str. 12, Lviv, 79013, \\ Ukraine \\ ${ }^{3}$ Department of Administrative-Legal Disciplines, Lviv State University of Internal Affairs, Gorodotska Str. 26, \\ Lviv, 79000, Ukraine \\ ${ }^{4}$ Educational and Scientific Institute of Forestry and Landscape Management, Ukrainian National Forestry \\ University, The general Chyprinka Str. 103, Lviv, 79057, Ukraine \\ * Corresponding author's e-mail: popovich2007@ukr.net
}

\begin{abstract}
The article is devoted to the study on the spatial distribution features of fungi-xylophytes and saprophytes - using the example of the oyster mushroom (Pleurotus ostreatus (Jacq.) P. Kumm.) in suburban plantations (Ukrainian Roztochya) and urbogenic conditions of the city of Lviv. The natural-climatic and forest-typological characteristics of the study region were revealed. Detailed attention was focused on the occurrence of this species in various types of plantings within suburban forest parks, parks, urban gardens and street plantings. The distribution of oyster mushroom individuals in the population was calculated according to the conventional Schwerdtfeger method. The urban-ecological conditions of the suburban and urban green plantings of the Lviv city revealed a high level of oyster mushroom (Pleurotus ostreatus (Jacq.) P. Kumm.) distribution, due to a set of favorable edaphoclimatic conditions of habitats, age and mechanical damage to trees. It was found that the distribution of the individuals in the suburban forests is half of that in the urban areas, which is confirmed by the calculation of variance (dispersion). The dispersion of oyster mushroom individuals in Lviv is $29.3 \mathrm{~m}^{2}$. With spontaneous arrangement of individuals, the value of the dispersion is approximately equal to the average value of the number of mushrooms in the population, while there is a tendency for accumulation of the studied macromycetes ( $22 \geq \mathrm{m})$. In urban plantings, the dispersion of individuals is twice as large as in forests, which indicates the wide possibilities for the oyster mushroom spores dispersal.
\end{abstract}

Keywords: oyster mushroom, Ukrainian Roztochya, xylophyte, saprophyte, macromycetes, destruction.

\section{INTRODUCTION}

Roztochya is a narrow range of hills in the west of Ukraine (Lviv region) and south-eastern Poland. It stretches from Lviv (in the south-east) to Tomashuv, Schebreshin and Krasnyck (in the north-west, Poland). The Roztochya forests are mixed (beech, fir, oak), pine forests grow on the sandy soils. The forests cover $40 \%$ of the territory, arable land covers an area of $30 \%$ of the total territory. Here run the boundaries of continuous distribution of fir, spruce, beech and larch. Roztochya is a climatic, floristic and faunistic border zone. In the region, there is high atmospheric precipitation (over $700 \mathrm{~mm}$ ), which causes a large accumulation of groundwater in the south-west. The representatives of the flora and fauna of Podillya, Polissya, the Ukrainian Carpathians, as well as common European species occur in Rostochya (Adryanov, 1951; Marynych, 1989). On the territory of Roztochya (within Ukraine), protected areas were established, including: Yavoriv National Natural Park, Natural Reserve Roztochya, Regional Landscape Park Ravske Roztochya, Zavadiv Reserve, Reserve Gryada, Reserve Tract Zhury (Alekseev, 1990; Gorban, 2016). 
The eastern part of the Ukrainian Roztochya is called Lviv Roztochya and comprises the forest stands of the complex green zone of the city of Lviv (Alekseev, 1987; Mukha, 2010). They are represented by oak-hornbeam-beech, hornbeamoak-beech and pine forests of fresh and partially moist site types (Brunets, 2013).

During the route surveys of the forests of the peripheral part (the Bryukhovychy forest district of Lviv region), as well as of the parks and gardens of the city of Lviv (Ukraine), the natural renewal and distribution of the oyster mushroom on the tree trunks was identified (Berezhny, Shyshova, 1972) (Fig. 1).

Oyster mushroom (Pleurotus ostreatus (Jacq.) P. Kumm.) is a saprophyte (xylophyte) which is widespread in temperate forests. It grows in groups, rarely - individually, on stumps, on dead or living, but weakened, trees of different hardwood species (oak, birch, rowan, aspen, willow), very rarely on the trees of coniferous species in broadleaved and mixed forests, parks and gardens. On the tree trunks, it is found quite high above the ground.

Oyster mushrooms often grow in thick clusters of 30 or more fruiting bodies that grow together at the base to form a kind of "multi-tier structures". They appear from September to November-December (mass fruiting occurs at the end of September-October), and are resistant to freezing. Under favorable conditions (cold weather), they may appear in May-June (Bysko, Dudka, 1987).

The oyster mushroom causes white flaky rot of tree trunks of hardwood species, less often - in coniferous species. Infection usually occurs through frost cracks and mechanical damage. Fruiting bodies of the mushrooms are formed in the place of the greatest development of rot.
The mushroom continues to grow and develop on dead wood (Aliyev, Smirnov, 1987).

The study of the Pleurotaceae family and the Pleurotus genus, which, according to the biological classification, includes the species of oyster mushroom (Pleurotus ostreatus (Jacq.) P. Kumm.), has been conducted by a number of Ukrainian and foreign researchers. Much attention was given to the study of the peculiarities of the morphological and biological characteristics, the place occupied by this species in the kingdom of Fungi (Zadražil, 1978; Černy, 1989; Pavlík, 2005, 2013), the peculiarities of cultivation, growth and the use of Pleurotus ostreatus in pharmacology, medicine, cooking (Gregory et al., 2007). The effect of ambient temperature and humidity on extensive cultivation of the oyster mushroom (Pleurotus ostreatus (Jacq.) P. Kumm.) was also studied (Popovich et al., 2019).

\section{MATERIALS AND METHODS}

Using the route ecological-comparative method of research, the peculiarities of the oyster mushroom occurrence under various environmental conditions of forests, gardens, parks and other green plantations of the city of Lviv were revealed (Table 1; Table 4).

The research was carried out during the fruiting period of the oyster mushroom in the Bryukhovychy forest district of the Lviv region - in spring (April-May) and autumn (October-November) 2017-2018. In the experimental plot, two parallel transects of east-west direction were laid. The first included the compartments -35 , $36,37,38$ of the Bryukhovychy forest district, and the second one $-39,40,41,42,43$.

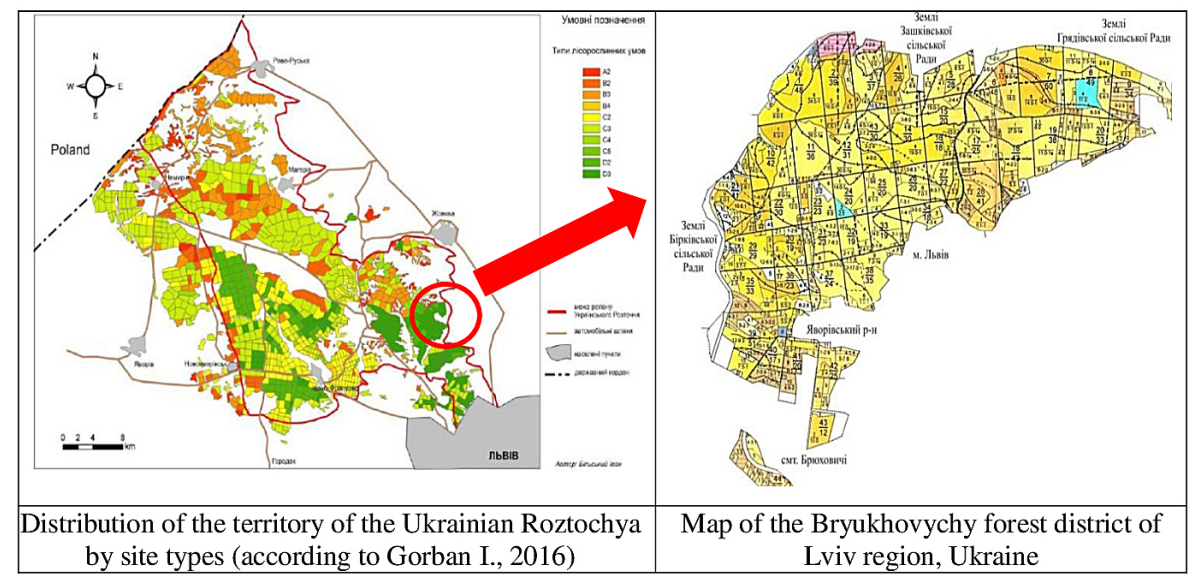

Fig. 1. Mapping of the experimental transects of the Bryukhovychy forest district, Ukraine 
Taking into account the saprophytic peculiarities of the oyster mushroom nutrition, the nature and origin of the woody substrate, as well as infection channels (cracks, wind breakage, branch breaking-off, whipping, cancer damage) were investigated. The distribution of individuals in the population was studied by Schwerdtfegger's technique (1968).

The dispersal of oyster mushroom individuals is calculated by the following dependence:

$$
S^{2}=\frac{\sum(x-m)^{2}}{n-1}
$$

where: $S^{2}$ - is the dispersal of oyster mushroom individuals;

$x$ - is the average number of individuals in the samples;

$m-$ is the number of individuals in each sample;

$n-$ is the number of samples.

\section{RESULTS AND DISCUSSION}

\section{Development of oyster mushroom in suburban forest}

The forests of the Bryukhovychy forest district, especially those which are part of the forest-park zone (compartments 32-38) as well as communal ones (compartments 39-43), are under considerable permanent anthropogenic pressure. Recreational activities in these forests lead to high stages of digression (the third and fourth degrees), is accompanied by significant trampling of the grass cover, various mechanical damage to trees and shrubs. Subsequently, they become victims of xylophytic fungi and saprophytes, among which the oyster mushroom is a common species.

At the same time, important indicative peculiarities of the species were taken into account, namely: the distribution in oak-type forests with giving preference to the beech forests, where the oyster mushroom infects the neighboring broadleaved species and only very rarely - pine and spruce (Černy, 1989).

In the places where the fruiting bodies of the oyster mushroom were found, the plant association was described, specifying the type of site conditions, as well as the forest type (Table 1; Fig. 2).

As can be seen from Table 1 and Figure 2, the oyster mushroom is mainly $(66.6 \%)$ found in fertile oak forest types, more rarely - in fairly fertile oak forest types (20.8\%). As expected, based on literary sources (Dudka, Wasser, 1980), it is quite rarely (14.6\%) found in pine forests.

Černy (1989), who examined the beech forests of the former Czechoslovakia, lists the destroyers of beech wood: brittle cinder (Hypoxelon deustum (Hoffm.) Grev..), tinder fungus (Fomes fomentarius (L.) J.J. Kickx.), dryad's saddle (Polýporus squamósus (Huds.) Fr.), artist's bracket (Ganoderma applanatum (Pers.) Pat.), shelf mushroom (Ganoderma inaccum Karst.), black bracket (Phellinus nigricans (Fr.) P. Karst.), willow bracket (Phellinus igniarius (L.) Quél.). All of these xylophytic fungi are wood-destroying species which prepare the substrate for saprophytes such as the oyster mushrooms.

In the course of our route studies, the following types of Polyporaceae were found in various forest biogeocoenoses: tinder fungus, false tinder, oak false tinder, oak tinder, birch fungus, aspen fungus.

Tinder fungi - (Polyporaceae Fr. ex Corda.) a group of mushroom family with common features: fleshy, leathery or woody tissue of fruiting bodies, with various types of hymenophore: tubular, twisted, dentate-split, labyrinth-like or gill-bearing. They grow exclusively on wood. Fruit bodies come as prostrate (flat) (up to $1 \mathrm{~m}$ in length), prostrate-bent, sessile (with diameter from $0.5-1 \mathrm{~cm}$ to $70 \mathrm{~cm}$ ), differentiated into cap and stipe. The mycelium of tinder fungi is perennial. The fruiting bodies persist from two weeks to $20-25$ years (Vorobyov, 1985). Taking into account the period of mycelium life-time, the high probability of spreading of Polyporeceae in the forests of Lviv Roztochya was noted. The destructors will be followed by the spread of saprophytic fungi-oyster mushroom and honey fungi, which will negatively affect the health of forest ecosystems (Zadražil, 1978).

The analyzed condition of the objects, on which the fruiting bodies of the oyster mushroom were found, showed that there were 17 occurrences on living trees, 3 - on dead standing trees, $5-$ on the fallen dead branches, and $9-$ on the stumps (Fig. 3). By place of attachment of fruiting bodies, the following occurrences were found: root -8 , butt -3 , trunk -7 , branches -1 (Fig. 4). The following damages contributed to the infection of the trees (Fig. 5): frost cracks -2 cases, bark scorch -1 , cancer -3 , wind breakage -7 , 
Table 1. Distribution of the oyster mushroom and the nature of its attachment to the substrate in the gardens and parks of the city of Lviv

\begin{tabular}{|c|c|c|c|c|c|c|c|c|c|c|c|c|c|c|c|c|c|c|}
\hline \multirow{2}{*}{ 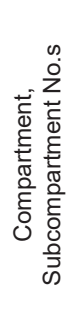 } & \multirow[b]{2}{*}{$\begin{array}{l}\text { Site } \\
\text { type }\end{array}$} & \multirow[b]{2}{*}{ Plant association } & \multirow[b]{2}{*}{$\begin{array}{c}\text { Main } \\
\text { woody } \\
\text { species }\end{array}$} & \multirow[b]{2}{*}{$\begin{array}{l}\text { Tree } \\
\text { age }\end{array}$} & \multicolumn{4}{|c|}{ Tree condition } & \multicolumn{4}{|c|}{$\begin{array}{c}\text { Place of attachment } \\
\text { and the nature } \\
\text { of rot }\end{array}$} & \multicolumn{6}{|c|}{$\begin{array}{l}\text { Contributing factor of } \\
\text { Oyster mushroom origin }\end{array}$} \\
\hline & & & & & ) & 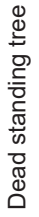 & 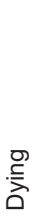 & 号 & 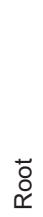 & 蒿 & $\begin{array}{l}\text { 돈 } \\
\stackrel{2}{ }\end{array}$ & $\begin{array}{l}\frac{c}{0} \\
\stackrel{\leftarrow}{\pi} \\
\frac{\pi}{\omega}\end{array}$ & 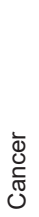 & $\begin{array}{l}\text { v } \\
\frac{\pi}{0} \\
\frac{\pi}{0} \\
\text { 芒 }\end{array}$ & 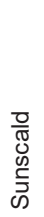 & 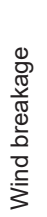 & . & $\begin{array}{l}3 \\
\text { 음 } \\
\text { 오 }\end{array}$ \\
\hline $\begin{array}{l}35,1 \\
33,0\end{array}$ & D2 & $\begin{array}{c}\mathrm{BE}+\mathrm{HBM}+ \\
\mathrm{POK}+\mathrm{SP}+\mathrm{EL}+ \\
\text { SPIT+SED+GE }\end{array}$ & $\mathrm{BE}$ & 110 & + & - & - & - & - & - & + & - & - & + & - & - & - & + \\
\hline $\begin{array}{l}35,1 \\
33,0\end{array}$ & D2 & $\begin{array}{l}\mathrm{BE}+\mathrm{HBM}+\mathrm{SBI}+ \\
\mathrm{POK}+\mathrm{SPIT}+\mathrm{ELD}\end{array}$ & $\mathrm{BE}$ & 110 & + & - & - & - & - & + & - & - & - & - & - & - & + & - \\
\hline $\begin{array}{l}35,3 \\
33,0\end{array}$ & $\mathrm{D} 2$ & $\begin{array}{c}\mathrm{BE}+\mathrm{HBM}+ \\
\mathrm{POK}+\mathrm{BI}\end{array}$ & BE & 120 & - & - & + & - & - & - & + & - & - & - & - & + & - & - \\
\hline $\begin{array}{l}35,4 \\
33,0\end{array}$ & $\mathrm{D} 2$ & $\mathrm{BE}+\mathrm{NOM}+\mathrm{HBM}+\mathrm{POK}+\mathrm{HAZ}$ & BE & 150 & + & - & - & - & - & + & - & - & - & - & - & - & - & + \\
\hline $\begin{array}{l}35,5 \\
33,0\end{array}$ & D3 & $\begin{array}{c}\mathrm{SBI}+\mathrm{NOM}+\mathrm{BE}+ \\
\mathrm{HBM}+\mathrm{SPIT}\end{array}$ & $B E$ & 70 & + & + & + & - & - & - & + & - & + & - & - & + & - & - \\
\hline $\begin{array}{l}35,1 \\
33,0\end{array}$ & D3 & $\mathrm{POK}+\mathrm{HBM}+\mathrm{SP}+\mathrm{BE}+\mathrm{DgW}+\mathrm{SPIT}$ & POK & 110 & + & - & - & - & + & - & - & - & - & - & - & - & - & + \\
\hline $\begin{array}{l}36,3 \\
23,0\end{array}$ & D3 & $\mathrm{BE}+\mathrm{HBM}+\mathrm{HAZ}$ & BE & 160 & - & - & - & + & + & - & - & - & - & - & - & + & - & - \\
\hline $\begin{array}{l}36,3 \\
23,0\end{array}$ & D2 & $\mathrm{BE}+\mathrm{HBM}+\mathrm{HAZ}$ & $B E$ & 130 & + & - & - & - & - & + & - & - & - & - & - & - & - & + \\
\hline $\begin{array}{l}37.5 \\
24.0\end{array}$ & D2 & $\mathrm{BE}+\mathrm{HBM}+\mathrm{NOM}+\mathrm{SP}+\mathrm{HAZ}$ & $\mathrm{BE}$ & 90 & + & - & - & - & - & - & + & - & - & + & - & - & - & - \\
\hline $\begin{array}{l}37.5 \\
24,0\end{array}$ & D2 & $\mathrm{BE}+\mathrm{HBM}+\mathrm{NOM}+\mathrm{ASP}+\mathrm{HAZ}$ & $\mathrm{BE}$ & 60 & + & - & - & - & - & - & + & - & - & - & - & + & - & - \\
\hline $\begin{array}{l}38,2 \\
35,0\end{array}$ & $\mathrm{D} 2$ & $\mathrm{BE}+\mathrm{HBM}$ & BE & 80 & - & + & - & - & - & - & + & - & - & - & + & - & + & - \\
\hline $\begin{array}{l}38,2 \\
35,0\end{array}$ & $\mathrm{D} 2$ & $\mathrm{BE}+\mathrm{HBM}$ & $\mathrm{BE}$ & 90 & - & - & + & - & - & - & + & - & + & - & + & - & - & - \\
\hline $\begin{array}{l}39,1 \\
51,0\end{array}$ & D2 & $\mathrm{BE}+\mathrm{POK}+\mathrm{HBM}+\mathrm{ELD}+\mathrm{SPIT}+\mathrm{HAZ}$ & $\mathrm{BE}$ & 120 & + & - & - & - & - & + & - & - & - & + & - & - & - & + \\
\hline $\begin{array}{l}39,4 \\
51,0\end{array}$ & D3 & $\mathrm{BE}+\mathrm{POK}+\mathrm{HBM}+\mathrm{SP}+\mathrm{ASP}+\mathrm{SBI}$ & POK & 100 & - & + & - & - & - & + & - & - & - & - & - & + & - & - \\
\hline $\begin{array}{l}39,4 \\
51,0\end{array}$ & D3 & $\mathrm{BE}+\mathrm{POK}+\mathrm{HBM}+\mathrm{SP}+\mathrm{ASP}+\mathrm{SBI}$ & POK & 60 & - & - & + & - & - & - & - & - & - & - & - & - & - & - \\
\hline $\begin{array}{l}39,6 \\
51,0\end{array}$ & C3 & $\begin{array}{c}\mathrm{BE}+\mathrm{POK}+\mathrm{SP}+ \\
\mathrm{HBM}+\mathrm{SBI}+ \\
+\mathrm{SPIT}+\mathrm{HAZ}\end{array}$ & BE & 100 & - & - & - & + & - & + & - & - & - & - & - & - & - & + \\
\hline $\begin{array}{l}39,6 \\
51,0\end{array}$ & C3 & Cutover area & $\mathrm{BE}$ & 200 & - & - & - & + & + & - & - & - & - & - & - & - & - & + \\
\hline
\end{tabular}

Note: Species codes (abbreviations for species names): SEDGE - Carex pilosa; AH - Ash; HBM - Hornbeam; SBI - Silver birch; POK - Common oak; ELD - European larch; SP - Scots pine; SY - Sycamore; EL - European larch; NOM - Norway maple; SPIT - European spindle tree; DgW - White dogwood; HAZ - Hazel; BE - Beech; ASP - Aspen; HCH - Horse chestnut; ROK - Red oak.

whipping -1 . The most common attachment of the oyster mushroom was observed on the butt part of the trunk (36\%), the least - on the branches $(3 \%)$, which is due to wood-destroying fungi, the members of Polyporaceae (Table 3).

The most favorable conditions for spores dispersal and the development of the fruiting bodies is the destruction with pronounced hollows $(50 \%)$ and wind breakage (24\%), which opens the tissue of trees for infection.

Within the study area, the tinder fungus, which is found on the beech trees (Fagus sylvatica L.), is the most widespread. On the oak trees (Quercus robur L.), the destruction of wood is caused by false tinder, oak bracket and robustus conk. On the aspen trees (Populus tremula L.), a powdery hollow was revealed as a result of rotting caused by aspen bracket. Oyster mushrooms were observed as well on a dead standing tree of weeping birch (Betula pendula Roth.), the decay was caused by birch mushrooms (Fig. 6).

An important factor in the distribution of Polyporaceae is the age of trees (Fig. 7). The 
Table 2. Occurrence of the oyster mushroom in the types of forest conditions and forest types

\begin{tabular}{|c|c|c|c|c|c|c|c|}
\hline \multirow{2}{*}{ Site type } & \multicolumn{5}{|c|}{ Forest type } \\
\cline { 2 - 8 } & $\begin{array}{c}\mathrm{D}_{2}^{-} \\
\text {OKHBMBE }\end{array}$ & $\begin{array}{c}\mathrm{D}^{-} \\
\text {OKHBMBE }\end{array}$ & $\begin{array}{c}\mathrm{D}_{2}^{-} \\
\text {OKHBMBE }\end{array}$ & $\begin{array}{c}\mathrm{C}_{2}^{-} \\
\text {OKHBMBE }\end{array}$ & $\begin{array}{c}\mathrm{C}_{2}^{-} \\
\text {OKHBMBE }\end{array}$ & $\begin{array}{c}\mathrm{C}_{2}^{-} \\
\text {OKHBMBE }\end{array}$ & $\begin{array}{c}\mathrm{C}_{3-} \\
\text { OKHBMBE }\end{array}$ \\
\hline $\mathrm{D}_{2}$ & 7 & 2 & & & & & \\
\hline $\mathrm{D}_{3}$ & & & 7 & & & & 1 \\
\hline $\mathrm{C}_{2}$ & & & & 5 & 1 & & 1 \\
\hline $\mathrm{C}_{3}$ & & & & & & & 1 \\
\hline
\end{tabular}

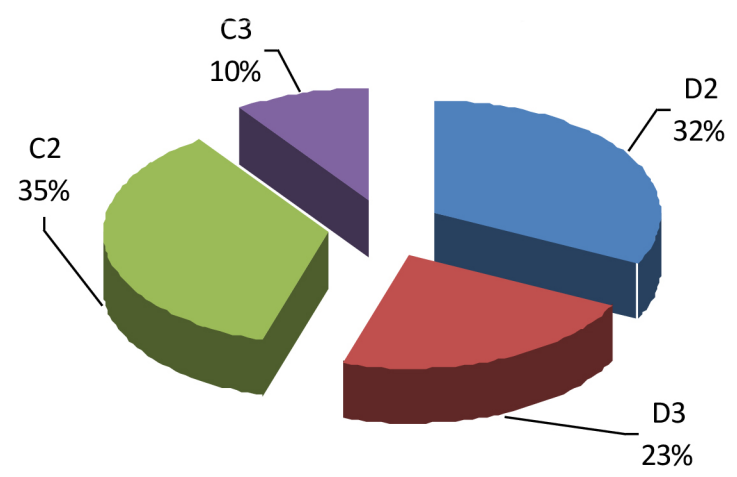

Fig. 2. Distribution of the oyster mushroom according to site types

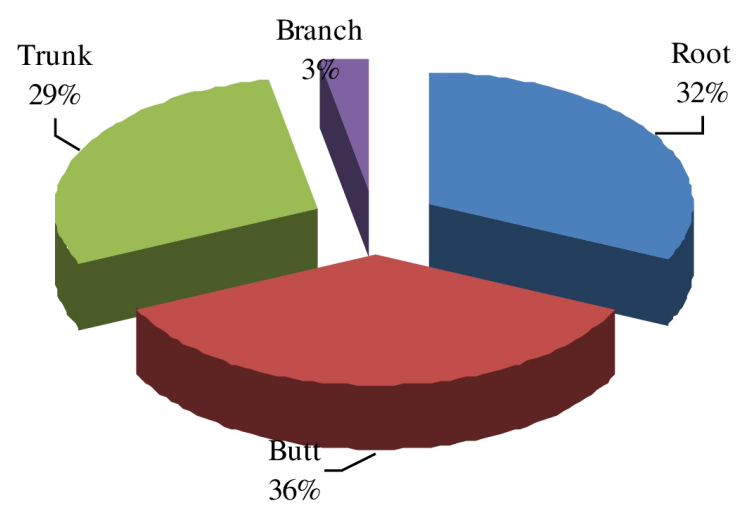

Fig. 4. Distribution of oyster mushroom fruiting bodies according to the place of their attachment to the substrate

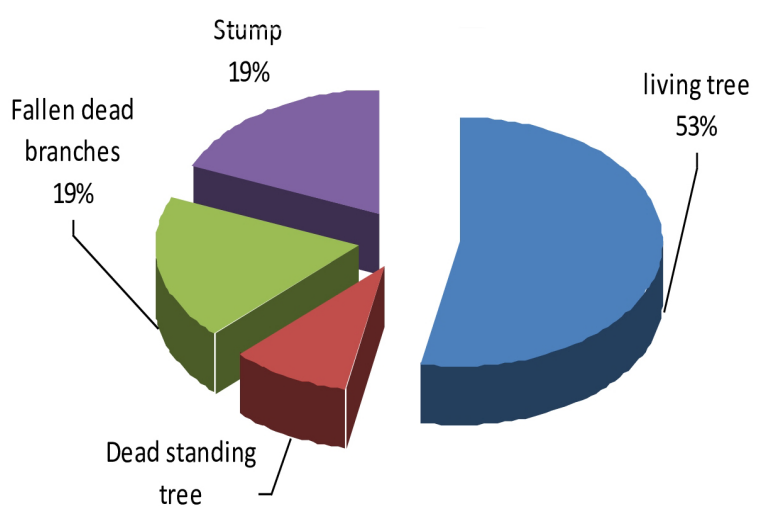

Fig. 3. Distribution of fruiting bodies of the oyster mushroom according to the condition of their attachment substrate

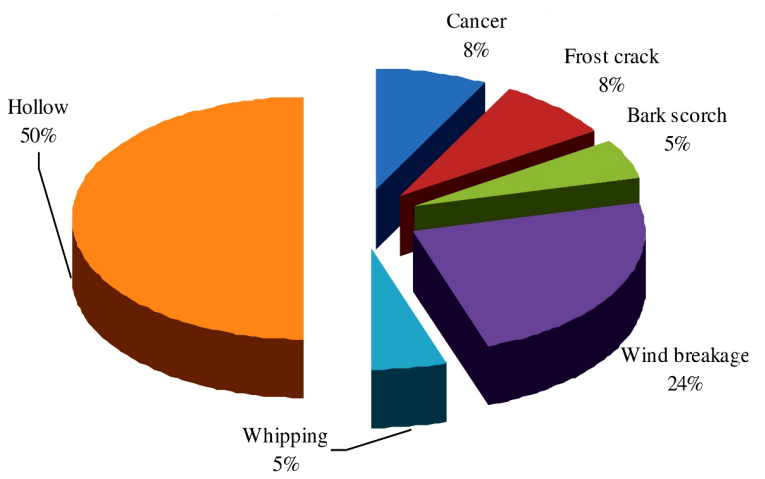

Fig. 5. Damage to trees which caused their infection by the oyster mushroom spores

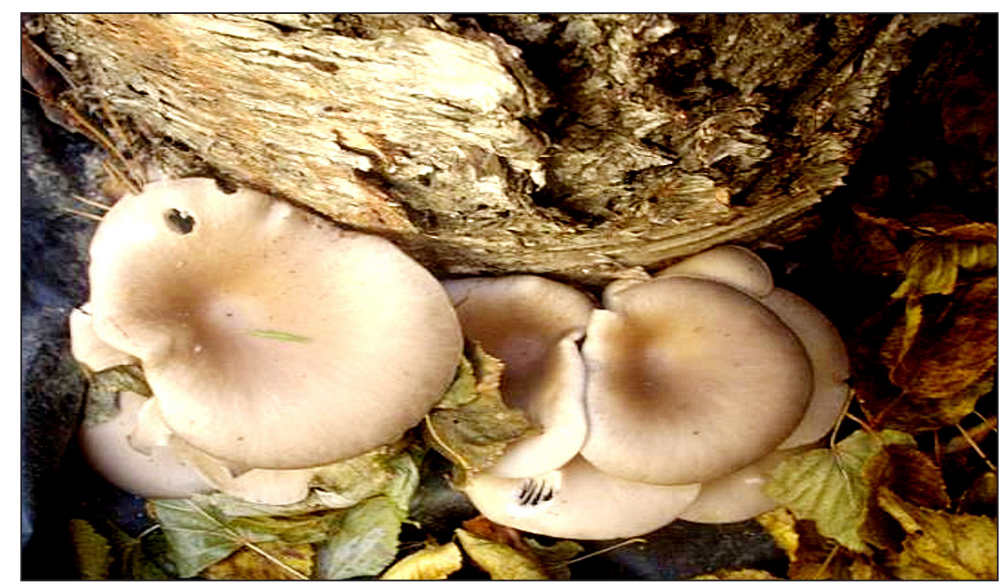

Fig. 6. Development of oyster mushroom fruiting bodies on the trunk of weeping birch 
Table 3. Growth of oyster mushroom on wood, destroyed by the wood-destroying fungi

\begin{tabular}{|c|c|c|c|c|c|c|}
\hline Species name & Tinder fungus & $\begin{array}{c}\text { False tinder } \\
\text { fungus }\end{array}$ & Robustus conk & Oak bracket & $\begin{array}{c}\text { Aspen } \\
\text { bracket }\end{array}$ & $\begin{array}{c}\text { Birch } \\
\text { mushroom }\end{array}$ \\
\hline $\begin{array}{c}\text { Number of species } \\
\text { individuals revealed }\end{array}$ & 8 & 3 & 2 & 2 & 1 \\
\hline
\end{tabular}

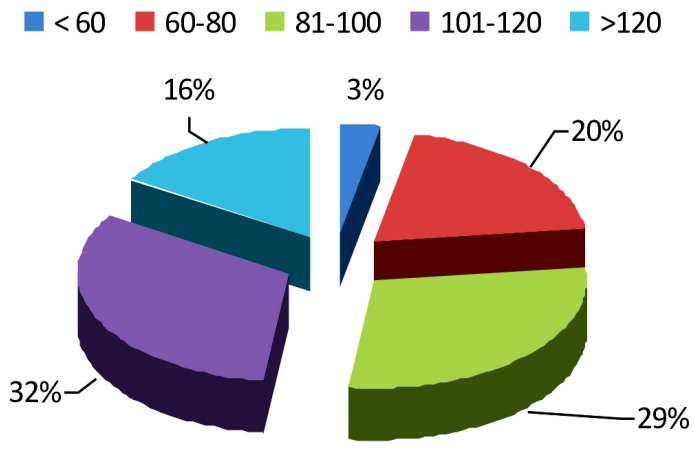

Fig. 7. Oyster mushroom occurrence on trees of different age groups

following trend was observed: On the trees aged 101-120 year and 81-100 years, the occurrence of oyster mushrooms was the highest $(32 \%$ and $29 \%$, respectively). The lowest distribution was observed for the trees under the age of 60 .

While analyzing the distribution and occurrence of the oyster mushroom within the investigated transept, it can be seen that the greatest occurrence of the mushrooms is observed in forest stands $-90 \%$, and on cutover areas - only $10 \%$ (Fig. 8). Such a ratio can be explained by the age (about 10 years) and the continuous canopy of the undergrowth and shrubs that appeared over the stumps after the main felling, and, as a result, a low level of insolation and poor ventilation (Piškur et al., 2011).

Using statistical methods of research, the peculiarities of distribution pertaining to the oyster mushroom individuals in the suburban forests were determined.

For the Ukrainian Roztochya forests, the area of dispersal of the oyster mushroom individuals constitutes $13.6 \mathrm{~m}^{2}$, which is less than in the green areas of the city (Table 1). This figure indicates lesser infestation of forest stands than that of the trees in gardens, parks and streets.

The foci of infection with the oyster mushroom spores are largely cutover areas (compartment 39, subcompartments 4,6 ) with stumps of beech and oak. As seen from Table 1, around the cutover areas were infected trees of weeping birch, aspen and Scots pine.

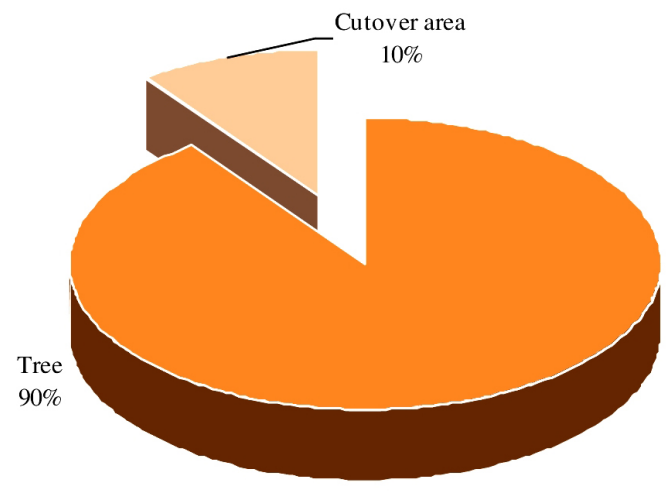

Fig. 8. Oyster mushroom distribution within stands and cutover area

On the basis of these studies, the authors arrived at a conclusion that the size of the objects of infection can be:

- large - cutover areas with stumps, overgrown with mushrooms;

- medium - a group of trees on which mushrooms settled;

- small - a separate tree, a stump, a dead standing tree.

\section{The development of oyster mushroom under urbogenic conditions of green spaces of Lviv}

The urban greening system, which has a radial-ring structure, includes three green rings. The first one is formed by plantings around the middle part of the city, located in the Lviv basin, where the slopes of the Castle hill descend. These are the plantings of the former Hetman's (Svobody ave.) and the Governor's (park on the Ramparts) ramparts, as well as plantations in the streets of Mitskevych, Galytska, Soborna, Mytna, the boulevard in Metropolitan Andrey street.

The second green ring is formed by the city parks: "High Castle", "Znesinnia", "Museum of folk architecture and everyday life" (the ridge of the Lviv Roztochya), Lychakivsky, Pogulyanka, Ecopark, Zalizna Voda, Stryisky, the B. Khmelnytsky recreation park, Students park, Sknylivsky, Zamarstynivsky, Kortumivka park, Levandivsky, Belogorshcha park, and the green area of the Yaniv cemetery which seems to close this ring. 


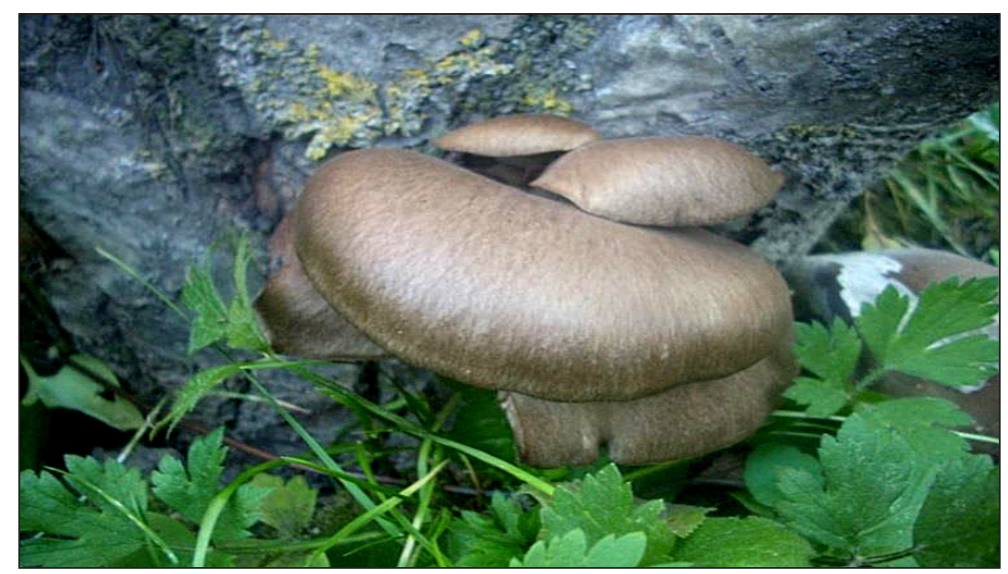

Fig. 9. Oyster mushrooms on a beech tree in Lviv Roztochya

The third green ring is made by numerous suburban forest parks: Vynnykivsky, Basivsky, Lypnykivsky, and Bryukhovytsky (Lviv Roztochya) (Didyk, Pavliv, 2006; Didyk, Maksymjyk, 2012; Kucheryavyy, 2017).

The radial system of the city greenery is formed by the street alleys and boulevards on which Norway maple (Acer platanoides L.), horse chestnut (Aesculus hippocastanum L.), smallleaved lime (Tilia cordata Mill.), sycamore (Acer pseudoplatanus L.), common ash (Fraxinus excelsior L.), downy ash (Fraxinus pubescens L.), silver maple (Ácer sacchárinum L.), and black poplar (Populus nigra L.) are planted. These trees, when damaged mechanically in varying degrees, are often infected both by the xylophytic and saprophytic fungi.

The system of greening the city with its continuity and the interconnection of green areas with the ecological corridors of the streets, as well as the presence of numerous mechanical damages, is a very favorable ecological factor for increasing the population size and density of the oyster mushroom, its distribution in gardens and parks, street plantings (Table 4).

Individuals of the oyster mushroom were found on the following trees: small-leaved lime (Sichovykh Striltsiv st.), horse chestnut (Bilotserkivska st.) (Fig. 11), white poplar (Chervona Kalyna ave., Shevchenko st.), ashleaved maple (box elder) (Valova st.), Chinese poplar (Shevchenko st.), European beech (Shevchenko grove, Pogulyanka, Stryisky park, Zalizna Voda park), small-leaved lime (park on the Ramparts), common oak (Shevchenko grove, Sykhiv forest park), weeping birch, aspen (Shevchenko grove), Norway maple (Stryisky park), and red oak (Shevchenko grove).
Taking into consideration the identified growth sites of the study fungus, it can be stated that the climatic and edaphic conditions of the city, regardless of their xerophytic nature, contribute to the development of this mushroom. The abundance of Pleurotus osteratus (Jacq.) P. Kumm., in the study areas was determined with the methods of Drude (1913) and Gaas (1932) (Table 5).

Thus, the smallest abundance of the macromycetes under study is inherent in the planting in the Zelena street, where populations of oyster mushroom are encountered singly (solitariae). The highest abundance was found in the plantings in Warshavska street., Krasna Kalyna ave., Lychakivska street; however, they do not create the background (copiosae 3). The mushrooms are encountered rarely, but scattered in small quantities in the plantings in Valova, Holovatsky, and Snopkivska streets (sparsae).

Comparing the habitats of the city and the suburban area, in particular the beech forests, it was found that they are characterized by a similar pattern of dispersal. This can be explained by the fact that the beech stands in Pogulyanka, Zalizna Voda park and Bryukhovychy Forest Park are in a state of collapse of their upper storeys; almost 150-year-old trees become weakened and, as a result, are infected and populated with saprophytes - oyster mushrooms.

The distribution of individuals in a population according to Schwerdtfeger (1968) may be random (spontaneous): an individual occurs very rarely in a homogeneous environment when organisms try to unite into groups; uniform: common under the conditions of strong competition, promotes uniform reproduction in space; nonuniform (group): organisms are trying to create groups, the distribution is close to the random 

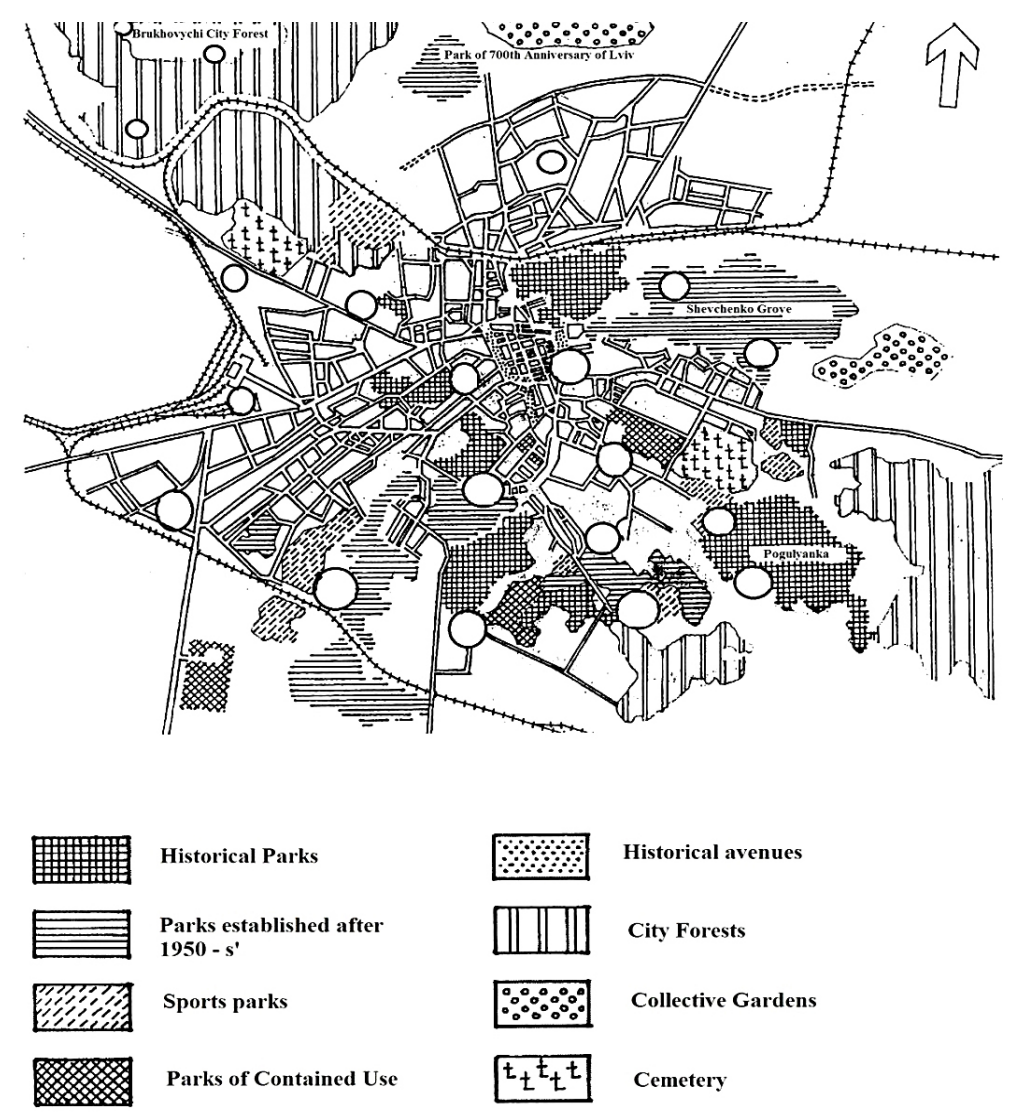

Places of detection Pleurotum osteratus

Fig. 10. Distribution of Pleurotus osteratus (Jacq.) P. Kumm. in the green plantations of the Lviv city (Didyk and Maksymjyk 2012)

Table 4. Distribution of the oyster mushroom and the nature of its attachment to the substrate in the gardens and parks of the Lviv city

\begin{tabular}{|c|c|c|c|c|c|c|c|c|c|c|c|c|c|c|c|c|c|c|}
\hline \multirow[b]{2}{*}{$\begin{array}{l}\text { Location } \\
\text { of } \\
\text { tree-substrate }\end{array}$} & \multirow[b]{2}{*}{ Single or group } & \multirow[b]{2}{*}{$\begin{array}{l}\text { Tree } \\
\text { species }\end{array}$} & \multirow[b]{2}{*}{ 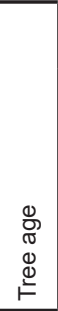 } & \multicolumn{4}{|c|}{ Tree condition } & \multicolumn{4}{|c|}{$\begin{array}{l}\text { Place of attachment } \\
\text { and the nature of rot }\end{array}$} & \multicolumn{6}{|c|}{$\begin{array}{l}\text { Contributing factors of oyster } \\
\text { mushroom origin }\end{array}$} & \multirow{2}{*}{ 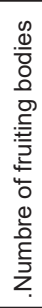 } \\
\hline & & & & 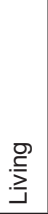 & 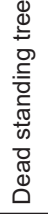 & 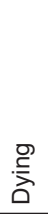 & 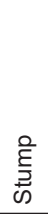 & 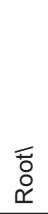 & 苛 & 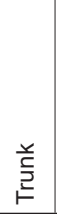 & $\begin{array}{l}\frac{c}{0} \\
\frac{0}{\pi} \\
\frac{\pi}{\omega}\end{array}$ & 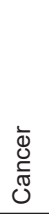 & 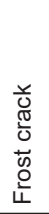 & 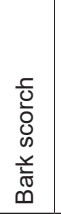 & $\begin{array}{l}\mathbb{\Xi} \\
\mathbb{\Xi} \\
\mathbb{\Xi} \\
\mathbb{\Xi} \\
\stackrel{\Xi}{0} \\
\stackrel{0}{\Xi} \\
\underline{\Xi}\end{array}$ & 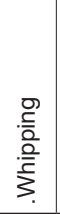 & $\begin{array}{l}\frac{3}{0} \\
\text { 음 } \\
\text { I }\end{array}$ & \\
\hline $\begin{array}{l}\text { Shevchenko } \\
\text { grove }\end{array}$ & POK+EL+EEL & Quercus robur L. & 50 & & & & + & & + & & & & & & + & & & 14 \\
\hline $\begin{array}{l}\text { Shevchenko } \\
\text { grove }\end{array}$ & OK+EEL & Quercus rubra L. & 60 & & & & + & & + & & & & & & & + & & 14 \\
\hline $\begin{array}{l}\text { Shevchenko } \\
\text { grove }\end{array}$ & $\mathrm{NOM}+\mathrm{AH}+\mathrm{SY}$ & $\begin{array}{l}\text { Acer platanoi- } \\
\text { des L. }\end{array}$ & 60 & + & & & & & & + & & & + & & & & & 8 \\
\hline $\begin{array}{l}\text { High Castle } \\
\text { park }\end{array}$ & $\mathrm{HCH}+\mathrm{SP}+\mathrm{HBM}$ & $\begin{array}{l}\text { Aesculus hip- } \\
\text { pocastanum L. }\end{array}$ & 70 & + & & & & & & + & & & & & + & & & 9 \\
\hline $\begin{array}{l}\text { Park on } \\
\text { Ramparts }\end{array}$ & $\mathrm{BE}+\mathrm{HBM}$ & Tilia cordata Mill. & 75 & + & & & & & + & & & + & & & & & & 7 \\
\hline Pogulynka park & $\mathrm{BE}+\mathrm{HBM}+\mathrm{HAZ}$ & $\begin{array}{l}\text { Fagus } \\
\text { sylvatica L. }\end{array}$ & 120 & + & & & & & & + & & & & & + & & & 11 \\
\hline Pogulynka park & $\begin{array}{l}\text { BE+HBM+NOM } \\
+\mathrm{ASP}\end{array}$ & $\begin{array}{l}\text { Fagus } \\
\text { sylvatica L. }\end{array}$ & 120 & + & & & & & & + & & & & & + & & & 12 \\
\hline $\begin{array}{l}\text { Zalizna Voda } \\
\text { park }\end{array}$ & $\mathrm{BE}+\mathrm{NOM}+\mathrm{ROW}$ & $\begin{array}{l}\text { Acer platano- } \\
\text { ides L. }\end{array}$ & 100 & + & & & & & & & + & & & & + & & & 4 \\
\hline Stryisky park & $\begin{array}{l}\begin{array}{l}\mathrm{NOM}+\mathrm{SY}+\mathrm{SBI} \\
+\mathrm{SP}\end{array} \\
\end{array}$ & $\begin{array}{l}\text { Acer pseudo- } \\
\text { platanus L. }\end{array}$ & 100 & & & & + & + & & & & & + & & & & & 6 \\
\hline Stryisky park & $\mathrm{NOM}+\mathrm{SY}+\mathrm{POK}$ & $\begin{array}{l}\text { Acer platano- } \\
\text { ides L. }\end{array}$ & 100 & + & & & & & & + & & & & & & & + & 10 \\
\hline Stryisky park & $\mathrm{NOM}+\mathrm{ROW}+\mathrm{SBI}$ & $\begin{array}{l}\text { Betula pendula } \\
\text { Roth. }\end{array}$ & 80 & + & & & & & + & & & & + & & & & & 6 \\
\hline
\end{tabular}




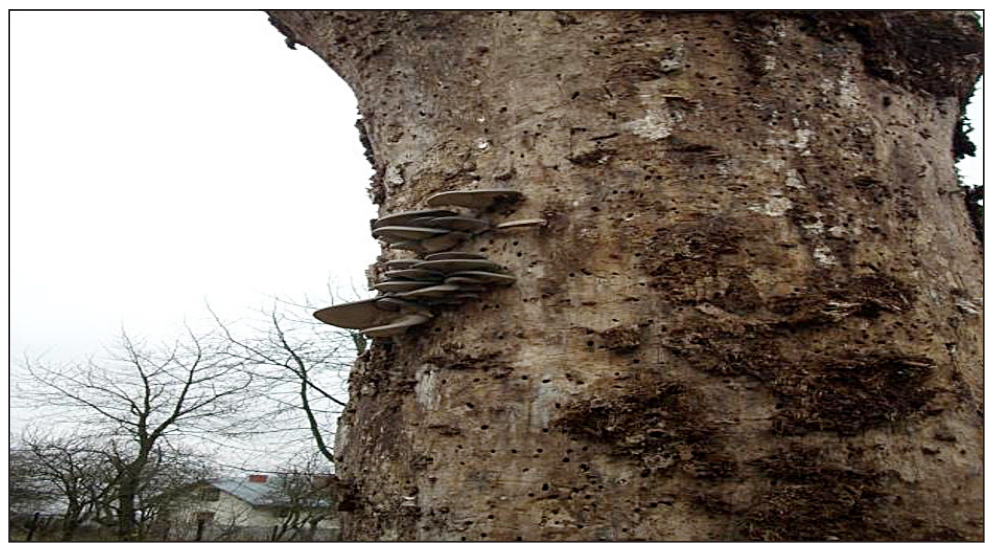

Fig. 11. Growth of the oyster mushrooms on a horse-chestnut tree (Bilyotserkivska st.)

one (Berezhny, Shyshova, 1972). The assessment of the spatial structure of the population depends on the average population density or the manner of the individuals spacing. Spontaneous distribution in the populations on the investigated trial sites is the characteristic of the oyster mushroom individuals.

The dispersal area of the population individuals of the oyster mushroom in the city of Lviv is $29.3 \mathrm{~m}^{2}$. At spontaneous distribution of individuals, the value for the dispersal is approximately equal to the average number of fungi in the population, while there is a tendency towards the clustering of the investigated macromycetes $(\mathrm{S} 2 \geq)$. The obtained value of the species dispersal is a conditional indicator, since the oyster mushroom, as shown above, develops in several coenotic environments. In urban plantings, the dispersal of individuals is more than twice as much as in the forest areas, which suggests, in our opinion, the greater possibility of the oyster mushroom spores dispersal.

The analyzed state of the trees on which the growth of oyster mushrooms was detected indicates that most of the tree damage is of destructive nature, which is caused by the xylotrophic activity. Table 6 shows the dispersal of Pleurotus ostreatus (Jacq.) P. Kumm. individuals in the populations depending on woody species.

The best development of the oyster mushroom in the suburban woods is found on the trunks of Populus tremula L. The same is true for the urban environments.

The destruction of wood is associated with the development of mycelium and the formation of fruiting bodies. The conducted laboratory studies showed that the wood of shoots of rowan (Sorbus aucuparia L.), Norway maple
(Acer platanoides L.), European hazel (Corylus avellana L.) was almost completely destroyed by fungi hyphae within one year of development (Fig. 12).

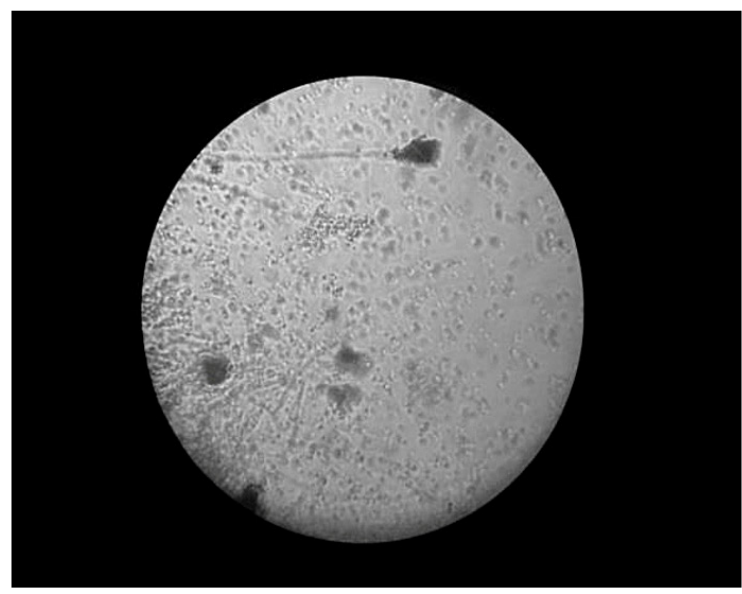

A

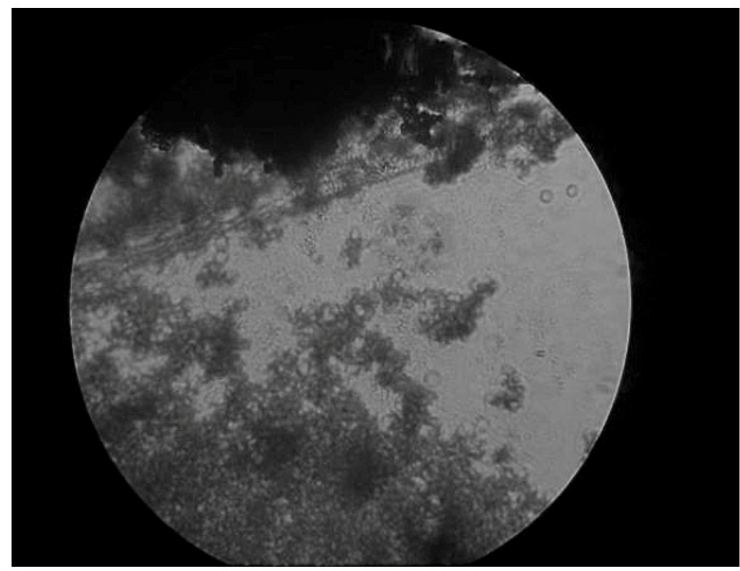

B

Fig. 12. Destruction of Norway maple wood by the oyster mushroom hyphae: A) at the beginning; B) in six months 
Table 5. Pleurotus osteratus L. abundance

\begin{tabular}{|c|c|c|}
\hline $\begin{array}{c}\text { The name of the street in Lviv where the growth } \\
\text { sites of oyster mushroom were found }\end{array}$ & $\begin{array}{c}\text { Abundance } \\
\text { (Drude (1913)) }\end{array}$ & $\begin{array}{c}\text { Abundance } \\
\text { (Haas (1932)) }\end{array}$ \\
\hline Valova st. (park) & sparsae & 3 \\
\hline 29b Holovaty st. & sparsae & 3 \\
\hline 180 Shevchenko st. & copiosae 3 & 5 \\
\hline 109 Zelena st. & solitariae & 1 \\
\hline Snopkiv park & sparsae & 3 \\
\hline 5 Chervona Kalyna ave. & copiosae 3 & 5 \\
\hline Shevchenko grove & copiosae 3 & 5 \\
\hline
\end{tabular}

Table 6. Oyster mushroom abundance on the trees of different species

\begin{tabular}{|c|c|c|}
\hline Species & Abundance according to O. Drude & Abundance according to Haas \\
\hline Populus nigra L. & copiosae 3 & 4 \\
\hline Aesculus hippocastanum L. & copiosae 2 & 3 \\
\hline Populus tremula L. & socials & 5 \\
\hline Carpinus betulus L. & copiosae 2 & 3 \\
\hline
\end{tabular}

\section{CONCLUSIONS}

The urboecological conditions of the suburban and urban green plantings of the Lviv city are responsible for a high level of occurrence of the oyster mushroom (Pleurotus osteratus (Jacq.) P. Kumm.) due to a set of favorable edapho-climatic conditions of habitats, tree age and mechanical damage to trees. In the suburban forest, the species occurrence rate is half of that in the city, which is confirmed by the dispersal calculation. In the suburban forests, the oyster mushroom occurs most often on the beech trees, on weeping birch, aspen, and in the city - on black poplar, small-leaved lime, aspen, and horse chestnut.

\section{REFERENCES}

1. Adrianov M. 1951. Microclimatic features of the city of Lviv. Geographic collection of Lviv University. 1, 93-101.

2. Alekseev V. 1990. Some issues of diagnosis and classification of contaminated forest ecosystems. Forest ecosystems and atmospheric pollution. Leningrad: Nauka.

3. Alekseev Yu. 1987. Heavy metals in soils and plants. Leningrad: Agropropromizdat,

4. Aliyev E., Smirnov N. 1987. Technology of cultivating vegetable crops and fungi in under-cover soils. Moscow: Agropromizdat.

5. Berezhnyy I., Shyshova E. 1972. Wildlife of Lviv region. Vegetation. Lviv: Vyshcha shkola.
6. Brunets K. 2013. Historical genesis of pine forests in the Lviv Roztochya. Naukovyi visnyk of UNFU. (23.9), 384-389.

7. Bysko N., Dudka I. 1987. Biology of cultivation of edible fungi of the Pleurotus genus. Kyev: Naukova dumka.

8. Černy A. 1989. Parazitické Drevokazné houby. Praha: Ministerstvo lesniho a vodniho hospodárstvi a drevozpracujiciho prumyslu ČSR.

9. Didyk V., Pavliv A. 2006. Urban Planning. Lviv: NU Lviv Polytechnic press.

10. Didyk V., Maksymjyk T. 2012. Aesthetics and composition of the landscape. Layout design of objects: compositional and aesthetic principles. Lviv: Lviv polytechnics press.

11. Dudka I., Wasser S. 1980. Mushrooms in the wild and human life. Kyiv: Naukova dumka.

12. Gorban I. 2016. Adaptation Plan of Yavorivshchyna Local Communities (Roztochya, Lviv region) to the Consequences of Climate Change in Highly Protected Territory. Project "How to adapt to climate change for the sake of sustainable development of local communities in a territory with high conservation status". Public Institute for the Protection of Nature.

13. Gregori A., Švagelj M., Pohleven J. 2007. Cultivation technigues and medicinal properties of Pleurotus spp. Food Technology and Biotechnology. 45, 236-247.

14. Kucheryavyy V. 2017. Landscape architecture. Lviv: New world - 2000.

15. Marynych O. 1989. Geographical Encyclopedia of Ukraine. Kyiv:.The M.P. Bazhan's Ukrainian Soviet Encyclopedia. 
16. Mukha B. 2010. The Roztochya Landscape-Geophysical Institution of formation, development, scientific heritage. Lviv: The Ivan Franko LNU press.

17. Pavlík M. 2005. Growing of Pleurotus ostreatus on woods of various deciduous trees. Acta Edulis Fung. 12, 306-312.

18. Pavlik M., Pavlik Š. 2013. Wood decomposition activity of oyster mushroom (Pleurotus ostreatus) isolate in situ. Journal of forest science. 59 (1), 28-33.

19. Piškur B. et. al. 2011. Influence of Pleurotus ostreatus inoculation on wood degradation and fungal colonization. Bioresource Technology. 102,
10611-10617.

20. Popovich V., Les M., Shuplat T., Bosak P., Fitak M., Popovich N. The effects of temperature and moisture stress content on the extensive cultivation of the oyster mushroom. Bull. Iraq nat. Hist. Mus. (2019) 15 (4): 473-489 https://doi.org/10.26842/ binhm.7.2019.15.4.0473

21. Vorobiev G. 1985. Forest Encyclopedia. Moscow: Soviet Encyclopedia.

22. Zadražil F. 1978. Cultivation of Pleurotus. In: Chang S.T. Hayes W.A. (eds): The Biology and Cultivation of Edible Mushrooms. New York: Academic Press. 